\title{
"Influence of world stock markets on the development of the stock market in
}

Ukraine"

$\begin{array}{ll} & \text { Inna Shkolnyk (i) } \\ & \mathbb{R} \\ & \text { Serhiy Frolov (i) } \\ \text { AUTHORS } & \text { Volodymyr Orlov (i) } \\ & \text { Viktoriia Dziuba (i) } \\ & \text { Yevgen Balatskyi (D) } \\ & \text { R }\end{array}$

Inna Shkolnyk, Serhiy Frolov, Volodymyr Orlov, Viktoriia Dziuba and Yevgen $\begin{array}{ll}\text { BRTICLE INFO } & \text { Balatskyi (2021). Influence of world stock markets on the development of the } \\ \text { stock market in Ukraine. Investment Management and Financial Innovations, }\end{array}$ 18(4), 223-240. doi:10.21511/imfi.18(4).2021.20

DOI http://dx.doi.org/10.21511/imfi.18(4).2021.20

RELEASED ON Wednesday, 24 November 2021

RECEIVED ON Monday, 27 September 2021

ACCEPTED ON

Tuesday, 16 November 2021

\section{(c) EY}

LICENSE

This work is licensed under a Creative Commons Attribution 4.0 International License

JOURNAL "Investment Management and Financial Innovations"

ISSN PRINT $1810-4967$

ISSN ONLINE $1812-9358$

PUBLISHER

LLC "Consulting Publishing Company "Business Perspectives"

FOUNDER LLC "Consulting Publishing Company "Business Perspectives"

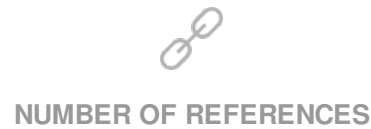

23
NUMBER OF FIGURES

10
琵

NUMBER OF TABLES

3

(C) The author(s) 2021. This publication is an open access article. 


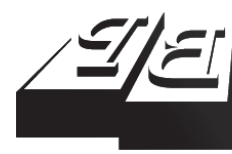

\section{BUSINESS PERSPECTIVES}

LLC "CPC "Business Perspectives" Hryhorii Skovoroda lane, 10 Sumy, 40022, Ukraine www.businessperspectives.org

Received on: $27^{\text {th }}$ of September, 2021 Accepted on: $16^{\text {th }}$ of November, 2021 Published on: $24^{\text {th }}$ of November, 2021

๔ Inna Shkolnyk, Serhiy Frolov, Volodymyr Orlov, Viktoriia Dziuba, Yevgen Balatskyi, 2021

Inna Shkolnyk, Dr., Professor, Department of Financial Technologies and Entrepreneurship, Sumy State University, Ukraine. (Corresponding author)

Serhiy Frolov, Dr., Professor, Department of Finance, Banking and Insurance, Sumy National Agrarian University, Ukraine.

Volodymyr Orlov, Ph.D. in Economics, First Deputy Head of the Dnipropetrovsk Regional State Administration, Ukraine.

Viktoriia Dziuba, Ph.D. Student, University of Customs and Finance, Ukraine.

Yevgen Balatskyi, Dr., Professor, Department of Financial Technologies and Entrepreneurship, Sumy State University, Ukraine.

Inna Shkolnyk (Ukraine), Serhiy Frolov (Ukraine), Volodymyr Orlov (Ukraine), Viktoriia Dziuba (Ukraine), Yevgen Balatskyi (Ukraine)

\title{
INFLUENCE OF WORLD STOCK MARKETS ON THE DEVELOPMENT OF THE STOCK MARKET IN UKRAINE
}

\begin{abstract}
Viewing the development of the stock market in Ukraine, the economy, which world financial organizations characterize as small and open, is largely determined by the trends formed by the global stock markets and leading stock exchanges. Therefore, the study aims to analyze Ukraine's stock market, the world stock market, stock markets in the regions, and to assess their mutual influence. The study uses the data of the World Federation of Exchanges and National Securities and Stock Market Commission (Ukraine) from 2015 to 2020. Stock market performance forecasts are built using triple exponential smoothing. Based on pairwise correlation coefficients, the existence of a significant dependence in the development of the world stock market on the development of the American stock market was determined. Regarding the Ukrainian stock exchanges, only SE "PFTS" demonstrated its dependence on the US stock market. The results of the regression model based on an exponentially smoothed series of trading volumes in all markets showed that variations in the volume of trading on the world stock market are due to the situation on the US stock markets. Trading volume dynamics on Ukrainian stock exchanges such as SE "PFTS" and SE "Perspektiva" is almost $50 \%$ determined by the development of stock markets in the American region. Although Ukraine is geographically located in Europe, the results show a lack of significant links and the impacts of stock markets in this region on the major Ukrainian stock exchanges and the stock market as a whole.
\end{abstract}

Keywords

JEL Classification

\section{INTRODUCTION}

The dependence of the stock markets' development on each other has become a focus of attention since the 2008 global financial crisis. Since then, it has been actively studied by scientists from different countries. This has led to the emergence of the so-called spillover effect, which manifests itself in the transfer of shocks from the stock market of one country to the stock markets of other countries. Quite often, the main source of infection is the world's largest stock markets, since their impact on smaller markets in most cases is decisive as confirmed by numerous studies. The current state of development of the stock market in Ukraine is determined by many factors. Since the Ukrainian economy is small and open to financial flows, the factors that shape external stock markets significantly affect the trajectory of its further development. Thus, there is a need for a structural analysis of its state, forecasts of trading volumes on the leading stock exchanges of Ukraine and the stock market as a whole, as well as for the study of the impact of the global stock market and stock markets of the US and European regions on the trends of its further development. 


\section{LITERATURE REVIEW}

The development of stock markets, as well as the existing dependencies, manifested in the spillover effect, have long been in the spotlight of scientists around the world and concern not only emerging, but also developed markets. Based on the study of the behavior of 49 stock indices reflecting the state of global stock exchanges (Lupu, 2015), the simultaneous presence of an intersection of values of different stock indices was confirmed, as well as the presence of regularities in the dynamics of their changes. Based on the Bloomberg data for 26 countries (Hurduzeu et al., 2021), it was found that Romania is the most dependent on the markets of developed countries such as Austria, Germany, the Netherlands, and to a lesser extent the United States. Among other EU countries, there is a dependence on the development of stock markets in the Czech Republic and Poland. Meanwhile, Romania exchanges bilateral shocks with countries such as Bulgaria and Hungary. Krkošková (2020) studied the relationship between stock markets of the Visegrad Four countries using the stock indices PX (Prague Stock Exchange index), SAX (Bratislava Stock Exchange), BUX (Budapest Stock Exchange), and WIG20 (Warsaw Stock Exchange), as well as their influence on economic growth. While studying the impact of global financial transformations on economic security in Central and Eastern Europe, Bulatova et al. (2020) found that challenges to economic security include the heterogeneity of these countries' financial development and high volatility of stock market capitalization.

Rai and Garg (2021) studied not only the state of stock markets, but also their development under the influence of the COVID-19 pandemic. The study examined the dynamic correlations and side effects of volatility between stock prices and exchange rates in the BRICS economies and their changes under the influence of the pandemic. It was found that during the COVID-19 outbreak, there were significant risk transfers between the two markets, which led to lower earnings on shares by national corporations and further capital outflows leading to higher exchange rates. Mishra and Mishra (2020) note that the COVID-19 pandemic created a spiral of recession in all major sectors of the economy, including the financial sector in the affected countries. In particular, after the outbreak and global spread of coronavirus in 2019, the stock markets of Asian countries immediately fell sharply, but at the same time formed certain volatility clusters. Such clustering of volatility arose primarily due to the pessimistic and panicky moods of investors.

Given the strengthening of ties between the economies of China and the United States, Zhang et al. (2021) studied the dynamic effects of the spread of volatility between the stock markets of these countries. A strong link between the volatility of the US stocks and the risk of the Chinese stock market collapsing was found, while the dynamic effects of the transfer were steadily increasing: as the US stock volatility grows, the risk of China's stock market falling increases. Diaz (2021) examines the transfer of volatility of major financial market indices in Greater China (EGCR): Shanghai Stock Exchange Index (SSEI), Hang Seng Stock Exchange Index (HSEI), Taiwan Stock Exchange Index (TIE), as well as the index of the Singapore Stock Exchange (STI). In particular, the highest volatility of the Shanghai Stock Exchange index was established, which is due to the low level of legislative protection of minority shareholders' rights.

Gulzar et al. (2019) studied the relationship between global stock markets and the stock markets of Asian countries. Caporale et al. (2019) investigated the relationships between the stock markets of China, Indonesia, Malaysia, the Philippines, Singapore, and Thailand based on the co-integration method proving the existence of long-term relationships with their gradual weakening after the global financial crisis.

The Tehran Stock Exchange was studied by Ebrahimi et al. (2016) and Hayati and Sedaghat (2016). The following key market development factors were identified: the size of companies listed on the Tehran Stock Exchange, return on investment, and performance of national companies.

It should be noted that in the stock markets of many countries, the main participants are banks that act as issuers of shares and corporate bonds, and as traders in securities. They also act as underwriters and market makers playing the lead- 
ing role and shaping trends in the development of stock markets. For example, Phuong (2021) argues that banks play a major role in the Vietnamese stock market and examines how COVID-19 affects bank shares and the state of the Vietnamese stock market. In addition, Nguyen (2021) similarly noted the role of bank stocks in the Vietnamese stock market and explored the main factors that determine their investment attractiveness. Salamat et al. (2021) note the importance of the role of bank shares for the Jordanian stock market.

The peculiarities of the development of the Ukrainian stock market are actively studied by Ukrainian scientists. For example, considerable attention is paid to the development of the Ukrainian stock market. Thus, Plastun et al. (2019) investigated the level of stability of different financial markets, both developed and emerging, FOREX markets, as well as commodity and cryptocurrency markets. It was found that market behavior differs on different days of the week and has differences in the long-term memory of market data behavior. Studying the financial security of Ukraine and Poland, Shkolnyk et al. (2020) analyzed the state of financial markets as the main elements influencing the level of financial security of these countries. Using the Eastern Partnership Association as an example, Shkolnyk et al. (2019) studied the relationship between the enhanced role of financial markets, which manifests itself in the financialization of the economy, and identified their role in shaping economic growth and financial security of countries. Oliynyk et al. (2017) investigated the possibility of using Ukrainian securities as financial investment instruments for life insurance companies.

Based on the literature review, it can be argued that the assessment of stock markets and factors that determine prospects for their development is relevant and in the spotlight of researchers from different countries. At the same time, many publications study the mutual influence of stock markets of different countries, especially the influence of developed stock markets on the markets of developing countries, border and small markets. Since Ukraine is a country with a small open economy, in order to understand the vector and dynamics of its stock market, it is important to confirm or refute the hypothesis of the impact of stock markets in certain regions of the world on the Ukrainian stock market and to forecast its further development.

\section{DATA AND METHODOLOGY}

The period 2015-2020 was chosen for this study due to several reasons. First, since 2015, statistical information does not reflect data from territories not controlled by Ukraine. Second, starting from 2015, financial regulators have taken certain reform steps both on the credit market by the National Bank of Ukraine and on the capital market by the National Securities and Stock Market Commission of Ukraine. This led to the transition of statistical indicators to a new relevant range that allows for a comparative analysis, not only in absolute but also in relative terms. A similar period was taken to build a regression model for the development of world stock markets.

The study tested the hypothesis of the existence of correlation and the impact of stock markets in certain regions of the world on the functioning of the stock market in Ukraine and individual stock exchanges, including in the future periods. The study was conducted in several stages and included structural analysis of the behavior of stock markets in three main regions - AsiaPacific, Americas, and Europe-Middle East-Africa (EMEA). It is based on the data from the World Federation of Stock Exchanges. Structural analysis of the stock market of Ukraine is based on the data from the National Securities and Stock Market Commission (Ukraine), as well as reports of the three main stock exchanges in Ukraine such as SE "PFTS", SE "Perspektiva", and SE "Ukrainian Exchange". A forecast with the determination of levels of low and high probability is built based on data on monthly trades volumes on the Ukrainian stock exchanges. The exponentially smoothed series is calculated as follows:

$$
L_{t}=k \cdot Y_{t}+1-k\left(L_{t-1}-T_{t-1}\right),
$$

where $L_{t}$ - smoothed value for the current period, $k$ - the smoothing coefficient of the series, $Y_{t}$ - the current value of the series, $L_{t-1}-$ the smoothed value for the previous period, and $T_{t-1}$ the trend value for the previous period. 
The triple exponential smoothing was used to build the forecast so that later values become more weighted than the values of the beginning of the analyzed period. The value of the confidence interval was set to standard at $95 \%$.

At the next stage, matrices of pair correlation between the stock exchanges of Ukraine, the total trading volume on the Ukrainian stock market, and the world stock market, as well as its American and EMEA regions, are formed. Before building linear regression models, time series characterization was performed, which describes trading volumes based on the use of the moving average method and the exponential smoothing method.

The moving average was calculated as follows:

$$
W M A=\frac{\sum_{i=1}^{n} P_{i}^{*} W_{i}}{\sum_{i=1}^{n} W_{i}},
$$

where $P_{i}$ - the value of trading in the $i$-period, $W_{i}$ - the value of scales for trading volumes in the $i$-period.

As a result of comparison of the obtained results for the building of linear regression models one used exponentially smoothed time series and determined the degree of influence of global stock markets on the functioning and prospects for further development of the Ukrainian stock market as a whole and Ukrainian stock exchanges in particular.

\section{RESULTS AND DISCUSSION}

As of 2020, the World Federation of Exchanges monitored and generated statistical information on 88 world stock exchanges, including 16 US exchanges, 22 exchanges in Asia, and 50 exchanges in the EMEA region. The total volume of stock exchange market capitalization in 2020 was USD $110,392,901$, and it increased by $18.9 \%$ (USD $17,554,902)$ compared to 2019. Figure 1 shows the structure of market capitalization of stock exchanges for the three main regions for which reporting is formed.

Ukraine is listed by the World Federation of Exchanges, but there is no data on Ukrainian stock exchanges. At the same time, even if the stock exchanges of Ukraine were listed, their market capitalization is extremely low and significantly smaller compared to the exchanges on the list. Figure 2 presents the results of calculating the share of major world stock exchanges in the total market capitalization. In 2020, more than $23 \%$ of the market capitalization was concentrated on the New York Stock Exchange (NYSE), and another $17 \%$ on the Nasdaq Stock Exchange (Nasdaq). As for the latter, it should be noted that compared to 2019, market capitalization increased by $46.6 \%$. It should be noted that in general, the American region accounts for almost $50 \%$ of the world market capitalization. In addition, the largest exchanges in the region include the TMX group (the share of which is $2.4 \%$ (2020)) and the Brazilian exchange - 1\%).

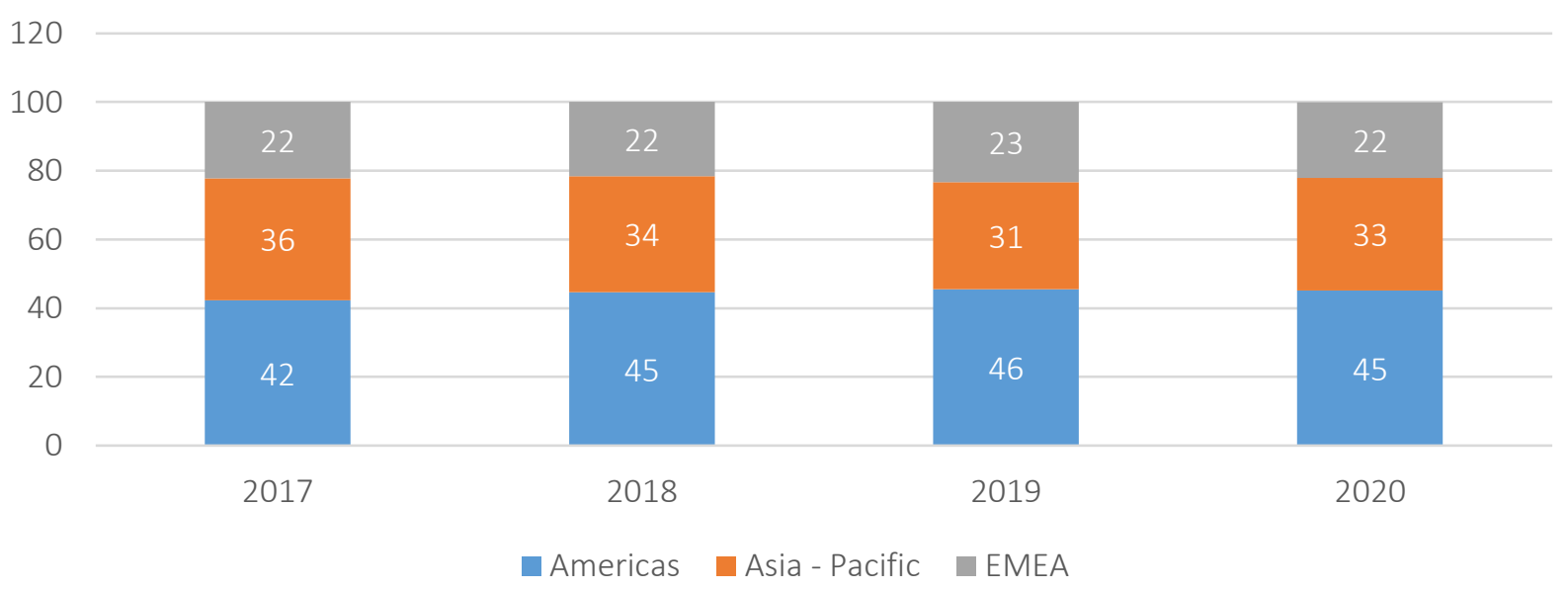

Figure 1. Market capitalization structure by main regions of the world stock market 

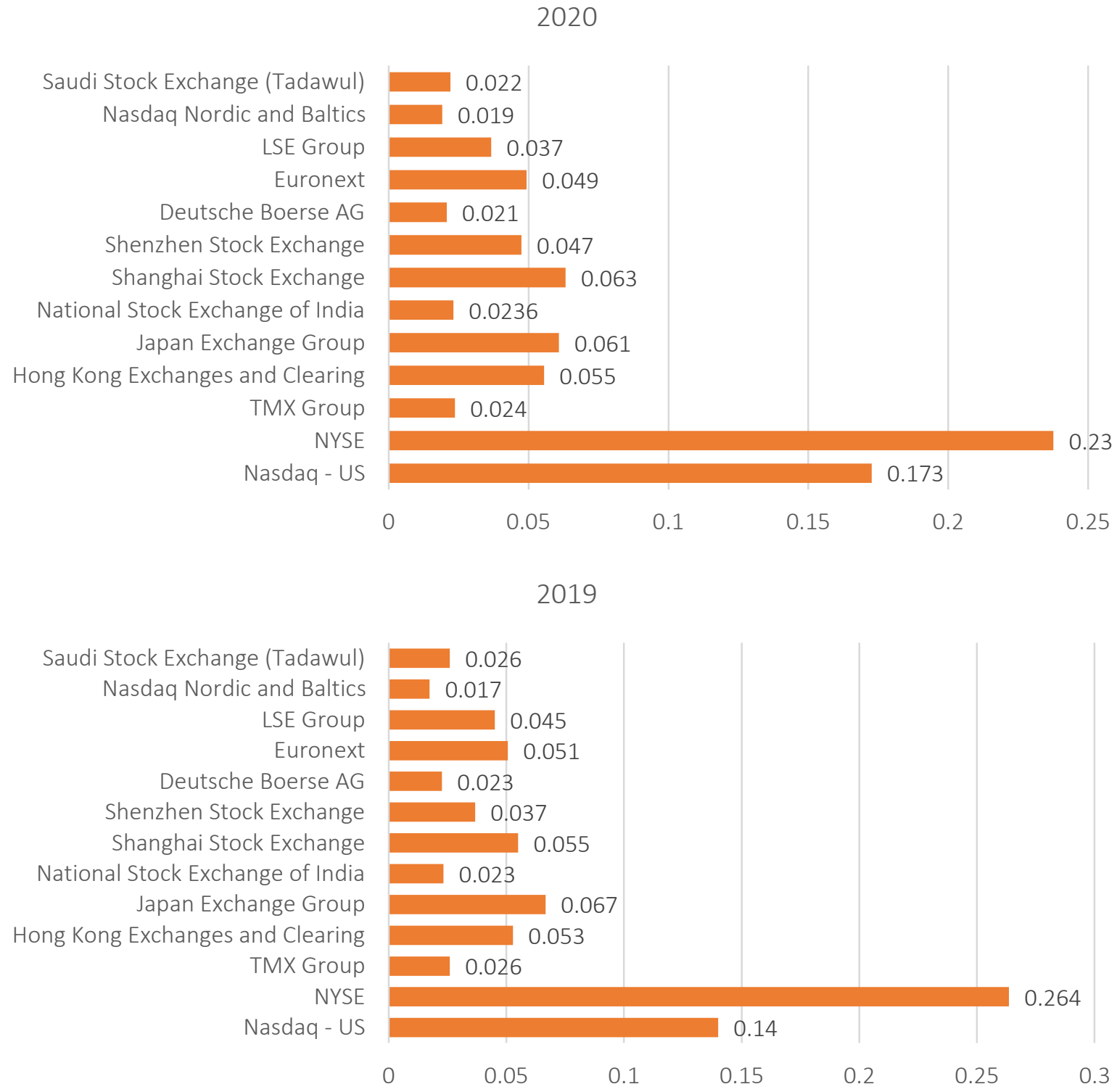

Figure 2. Share of the world's major stock exchanges in the total world market capitalization

The share of the Asian region in the total market capitalization is $32.7 \%$ (USD $36,153,300$ ), which is $1.5 \%$ more than in 2019. Among the exchanges of this region, which are included in the list of the world largest exchanges as of 2020, it is worth noting the Hong Kong Exchange and Clearing, the share of which is more than $5 \%$ (USD 6,130,420), and the Japan Exchange Group - 6.1\% (2020). In addition, the exchanges of this region include the National Stock Exchange of India, the share of which is more than $2 \%$, and the Shanghai Stock Exchange, the share of which is more than $6 \%$ in 2020 , and its market capitalization increased by almost 37\% compared to 2019.
As for the EMEA region, compared to the other two regions, its share is only $22 \%$ and, compared to 2019 , the loss of market capitalization in the structure of global capitalization amounted to $1.4 \%$ although the amount of capitalization in the region increased by more than $12 \%$. The biggest exchanges in the region are Euronext (Euronext) 5\%, LSE group, which includes the London Stock Exchange (London Stock Exchange) and the Italian Stock Exchange (Borsa Italiana); their total share is $3.7 \%$, which is $0.8 \%$ less than in 2019 . Among the stock exchanges of this region, the Warsaw Stock Exchange should be emphasized, the share of which in the total world market cap- 
italization in 2020 was only $0.2 \%$, but the growth rate for the year was more than $17 \%$. This stock exchange is often used by Ukrainian companies to conduct securities placement operations.

The current state of capital markets in Ukraine and, first of all, the stock market, can be characterized as one that cannot influence the processes of capital formation of companies in the real sector of the economy. From the point of view of world stock markets, the size of the Ukrainian stock market is insignificant and, therefore, it is not included in the list of countries in which stock markets are even minimally significant (Appendix A). According to the Financial Times Stock Exchange (FTSE), the Ukrainian market is not included in any of the groups by which stock markets are classified. In particular, according to the FTSE approach, as of March 2021, four groups of stock markets have been identified such as developed countries, advanced emerging countries, secondary emerging, and frontier countries. The first group includes stock markets of 26 countries that are economically developed and are leaders in the world economy. The second group includes 10 countries, the third - 14 countries, and the fourth - the maximum list of 30 countries the markets of which are characterized as marginal and have a share of less than $1 \%$ in the world market.

Like the FTSE index, which includes 80 countries, the Morgan Stanley Capital International World (MSCI) index also covers 80 countries and nearly $99 \%$ of the world stock markets. Unlike the FTSE index, the MSCI index classifies countries into four groups that differ in the composition of countries and the classification itself. The four groups include developed markets, which include 23 countries and do not include Poland and South Korea. South Korea is not included in the list of countries according to the MSCI index, and Poland is included in the group of countries with emerging markets. The latest group in this index is represented by 27 countries. The countries whose markets are defined as marginal are 19 countries, which is much less than in the FTSE index. However, the rating according to this index puts Ukraine in the group of countries with autonomous stock market indices. Together with Ukraine, 10 more countries are represented in this group.
The index basket of S\&P Dow Jones Indices includes 82 countries, which do not include Ukraine. Compared to the two previous indices, S\&P Dow Jones Indices forms only three groups of countries such as developed - 25 countries, which are almost completely correlated with the previous two, emerging markets -26 countries, and border markets -31 countries.

\subsection{Stock market conditions in Ukraine}

On the one hand, it is inappropriate to make a comparative assessment of the size of the Ukrainian stock market with the markets of other countries, as it cannot be comparable. However, on the other hand, the insignificant size of the stock market in Ukraine requires a study of its dependence on the impact of world stock markets and the formed trends.

The analysis of issues of registered securities in Ukraine shows that the main financial instrument presented on the stock market is government bonds, their share has a steady upward trend for the period 2015-2020. Their growth displaces the most significant securities for the development of companies not only in the real but also in the financial sector of the economy - there is a significant reduction in stock trading for six years from $2.09 \%$ to $0.18 \%$. Regarding corporate bonds, their share decreased even more from almost $5 \%$ in 2015 to $0.28 \%$ in 2020 . This situation is threatening in terms of further development of the country's financial system. It can be attractive only if the state guarantees and timely fulfills all obligations to service domestic government bonds.

The volume of registered issues of the National Securities and Stock Market Commission (Ukraine) is quite uneven during the analyzed period, but it is worth noting two large surges in the issuance of securities - in December 2016 and autumn 2017 (Figure 3). In the first case, the surge was due to the issuance of shares, which was carried out to recapitalize JSC Commercial Bank "Privatbank" after its nationalization. Therefore, this issue concerns the public finances. It should be noted that in this way the funds raised by the Ministry of Finance of Ukraine for recapitalization through the issuance of do- 
Source: Authors' calculations based on the data from the National Securities and Stock Market Commission (Ukraine).

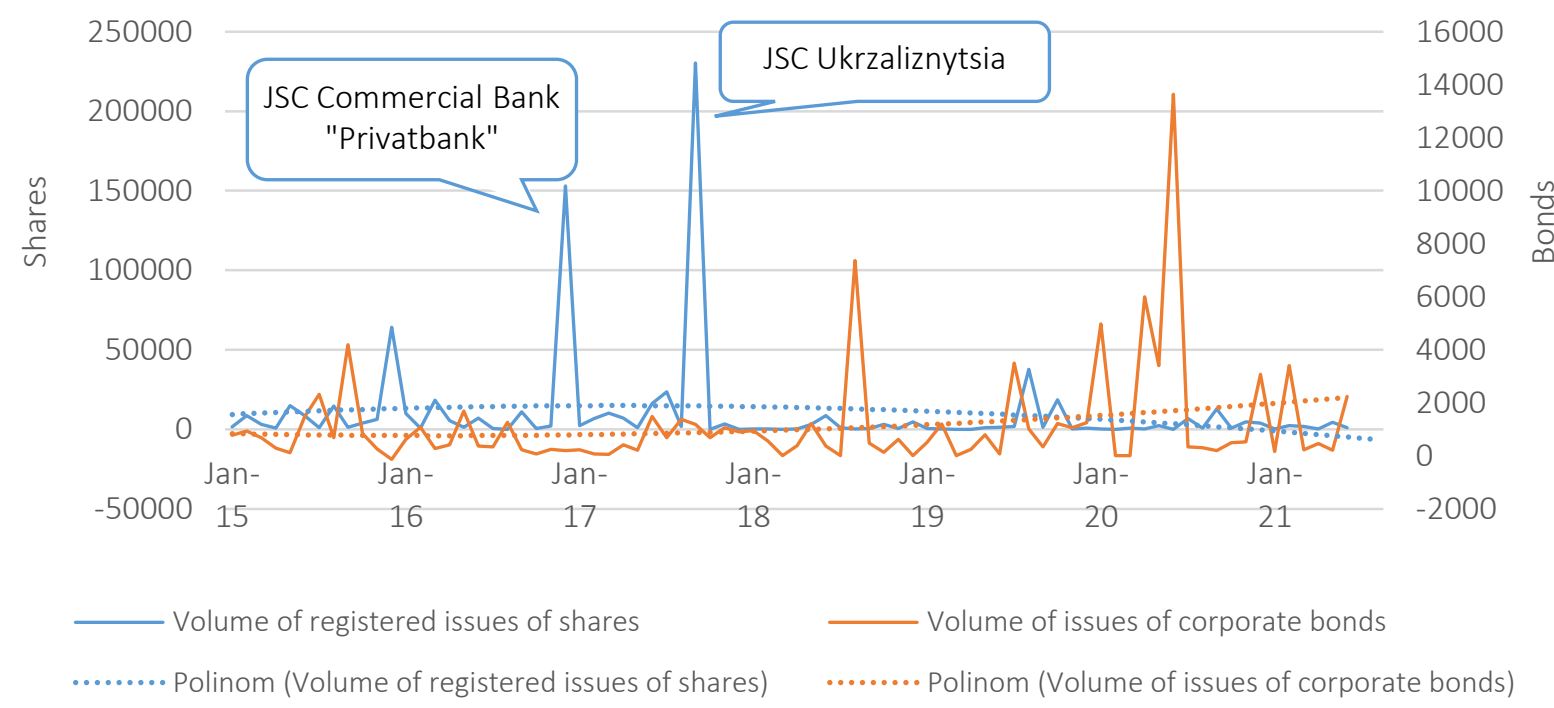

Figure 3. Volumes of registered securities issues in Ukraine, UAH mln

mestic government bonds into shares of JSC Commercial Bank "Privatbank" were essentially transformed.

The total amount of the issuance was UAH 146,238.2 million. In addition, in 2016, PJSC "State Export-Import Bank" was also recapitalized in the amount of UAH 9,319 million, and PJSC "State Savings Bank of Ukraine" in the amount of UAH 4,956 million. This also means that there was no real increase in capital, and operations were aimed at maintaining the liquidity of systemically important banks and banks under state control and, as a result, helped maintain the liquidity of the banking system as a whole. That is, due to the issuance of shares, with few exceptions capital did not come into the real sector of the economy. Regarding 2017, the issuance was also carried out to finance the state corporation JSC "Ukrzaliznytsia".

When compared to the issue of shares, the issue of corporate bonds was carried out to a much lesser extent. The maximum value of the corporate bonds issue was recorded in June 2020 and amounted to UAH 13,642 million. In general, in 2020 bonds were issued for a total of UAH 32.75 billion. But the trend of the dominance of state-owned enterprises among issuers continues. In particular, in 2020 the main issuer of bonds was the state agency of highways - in the amount of UAH 19,274 million, as well as the state mortgage institution - in the amount of UAH 6,700 million. Among the is- suers of non-state forms of ownership that issued bonds the leaders were Nova Poshta LLC - in the amount of UAH 700 million and Best Leasing LLC - in the amount of UAH 210 million. The main issuance was made by a non-state-owned company LLC "Primorskaya Vielectroektantsiya-2" - in the amount of UAH 2,080 million. This company is part of DTEK Corporation and is one of the leaders in Ukraine among producers of renewable green energy. According to the data published on DTEK VDE's website, the company currently has three wind farms - Botiyevska Wind Power Plant (WPP), which was commissioned in 2012-2014, and Primorskaya WPP and Orel WPP commissioned in 2019. In addition, DTEK has two of the largest solar power plants in Ukraine - Pokrovska and Nikopolska. For the development of green energy in 2019, DTEK successfully placed green Eurobonds in the amount of EUR 325 million, which were listed on the Euronext Dublin Stock Exchange. It is not possible to obtain such funds on the Ukrainian stock market taking into account the low capacity and investment attractiveness at the present stage.

The characteristic feature of the Ukrainian stock market is the predominance of securities trading on the over-the-counter market. The volume of securities trading in 2017 was significantly reduced, by more than 4.5 times. Since 2017 , the volume of trades has gradually increased, and as of 2020 it has more than doubled, but the value of 2016 has not been achieved. A significant reduction in trad- 
ing volumes in 2016 was the result of the policy pursued by financial regulators, in this case, the National Securities and Stock Market Commission (Ukraine) to clean the market from low-quality, illiquid speculative securities. This primarily concerned trading in those securities that were traded on the over-the-counter market, its volume decreased in 2017 by more than 4.5 times, while the volume of trading on the stock market decreased by only $12.5 \%$, and in 2018 returned to the value at the level of 2016. Tightening the requirements for the quality of securities led to the cleaning of the over-the-counter securities market.

The calculated value of the pairwise correlation coefficient for the GDP indicator and the volume of securities trading for the analyzed period is -0.7469 , which indicates the presence of a fairly high closeness of the relationship between these indicators but of the inverse value. At the same time, the value of the pairwise correlation coefficient for the GDP indicator and the volume of trading on the stock market (0.5328) indicates a positive average level of closeness of the relationship between these indicators.

From the point of view of assessing the state of the stock market, it is more important to analyze the dynamics of indicators to GDP (Figure 4).

In 2017, the dynamics of securities trading relative to GDP showed a significant reduction, and if the absolute value decreased by 4.5 times, the relative indicator decreased by 5.7 times, and its recovery rate is much slower than the growth rate of absolute values. Thus, for the period from 2017 to 2020, the volume of securities trading in \% to GDP increased by only $52 \%$, while in absolute terms by $113 \%$. The reasons for this are not only changes in the securities market, but also in the dynamics of GDP itself, which at this time also showed a significant slowdown.

Analyzing the chain rate of changes in the volume of trading on the stock market to GDP, since 2017 the indicators tend to increase, but the rate of changes of market capitalization in \% to GDP has the opposite trend. This trend is explained primarily by the structure of trading on Ukraine's capital market. More than $90 \%$ of transactions in financial instruments are domestic government bonds, which increase the volume of exchange trading, but in no way affect the size of market capitalization, which is determined based on shares, and their share in the structure of financial instruments is gradually declining.

\subsection{Development of stock exchanges in Ukraine}

Given that the organized market plays an important role in terms of financing the activities of corporations, it is advisable to analyze the situation on the stock exchanges of Ukraine.

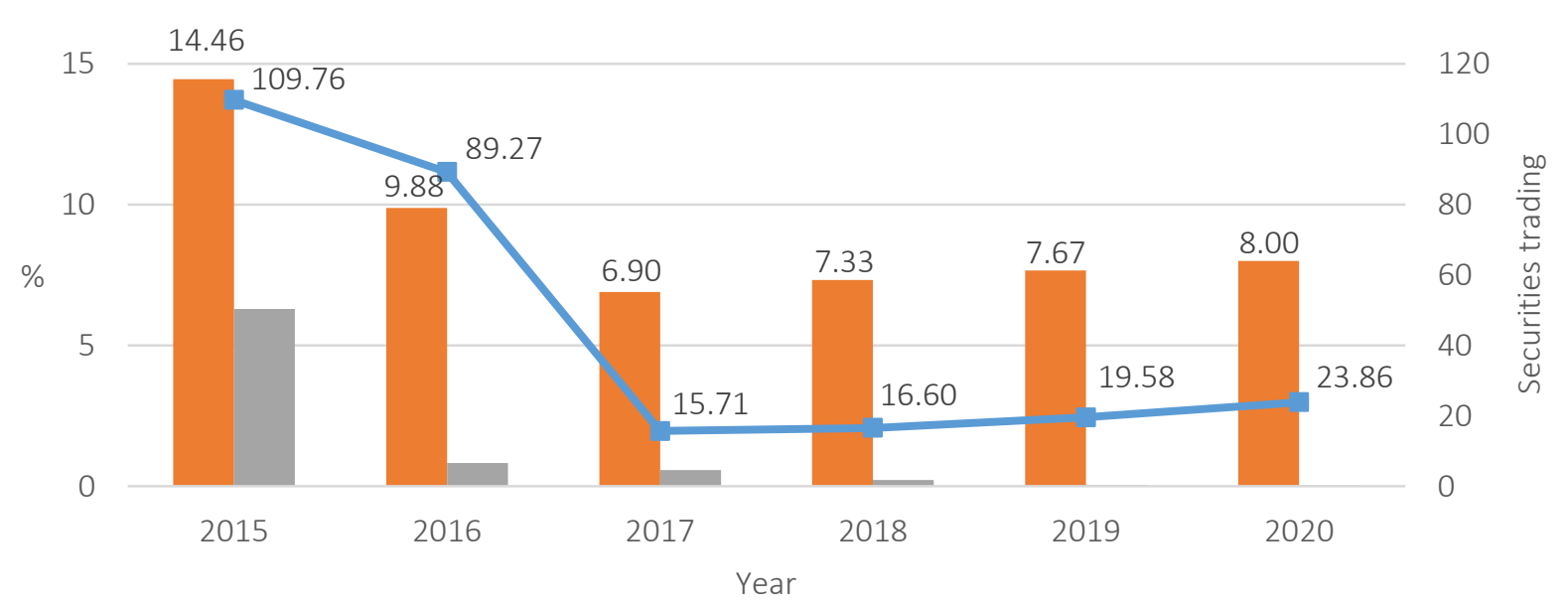

\footnotetext{
Volume of trading on the stock market to GDP,\%
}

Market capitalization to GDP\% Volume of securities trading to GDP,\%

Figure 4. Securities trading status and market capitalization in \% of GDP 


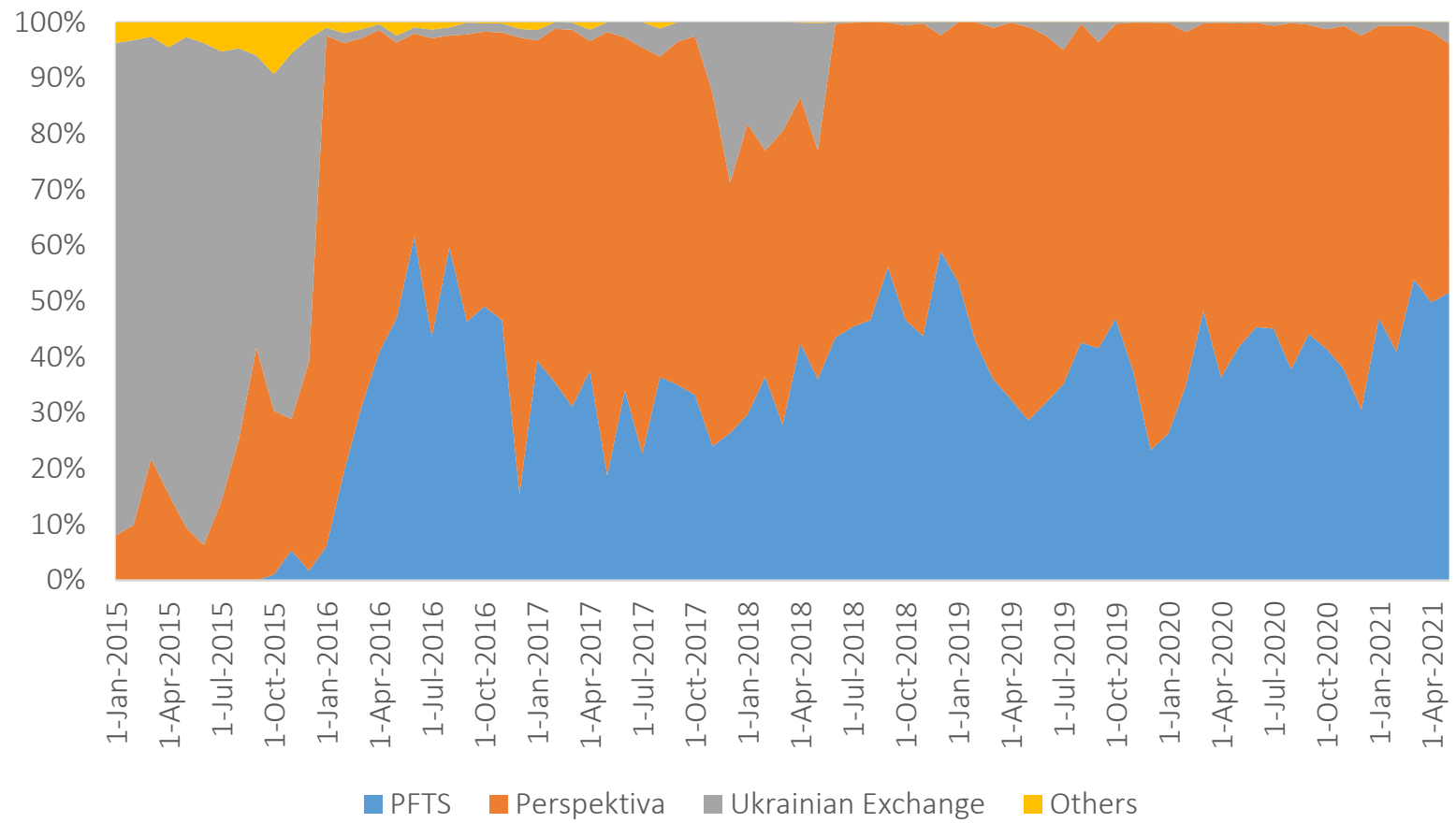

Figure 5. Structure of securities trading in terms of stock exchanges in Ukraine

Currently, in Ukraine the trading takes place on three major stock exchanges, namely JS SE "PFTS" (hereinafter - SE PFTS), JS "Ukrainian Exchange", and JS "SE" Perspektiva" (hereinafter - SE "Perspektiva"), two of which - SE "PFTS" and SE "Perspektiva" currently actually dominate the market. The ratio of trades for the period from 2015 to May 2021 varies significantly (Figure 5). Thus, during 2015, the bulk of trading was carried out on JSC "Ukrainian Exchange", but as of January 2015, the share of the exchange was almost $88 \%$ and gradually decreased to $60 \%$, then as of January 2016 , the trading on this stock exchange was only $1.5 \%$.

Gradually, the trading ratio between SE "PFTS" and SE "Perspektiva" leveled off and today fluctuates almost in the ratio of 1:1. It should be noted that since the beginning of 2021 SE "Ukrainian Exchange" has been gradually increasing trading volumes. At the beginning of the year, its share was only $0.6 \%$, but as of June 2021, the share of the exchange market in trading increased to $5 \%$.

The analysis of the trading status and the structure of securities transactions in terms of stock exchanges shows that SE "PFTS" and SE "Perspektiva" mainly service transactions with domestic government bonds (Figure 6). Their share is gradually displacing the volume of transactions with other financial instruments, which should be basic, stocks and corporate bonds. Thus, in the 2019 and 2020 trading structure, "Perspektiva" stock exchange has exclusively domestic government bonds. At the same time, there is almost no trading in shares on this stock exchange. As a result, the index of this stock exchange is not calculated. In fact, the set of financial instruments on "Perspektiva" stock exchange is non-diversified. The functioning of this stock exchange is practically irrelevant to corporate finance.

A certain share of corporate securities transactions is carried out on SE PFTS. The operations carried out on SE "Ukrainian Exchange" are maximally diversified, although in the context of each year presented in Figure 4, the structure of operations is unstable. At the same time, shares and bonds are presented almost every year. Unfortunately, the trend of replacement of corporate securities with domestic government bonds continues, which is confirmed by the structure of operations on all stock exchanges in 2020.

These conclusions are confirmed when analyzing detailed distribution of securities transactions among stock exchanges (Figure 7), namely, transactions with shares take place mainly on SE "PFTS" and SE "Ukrainian Exchange". 
Source: Compiled by the authors based on stock exchangesə reports.
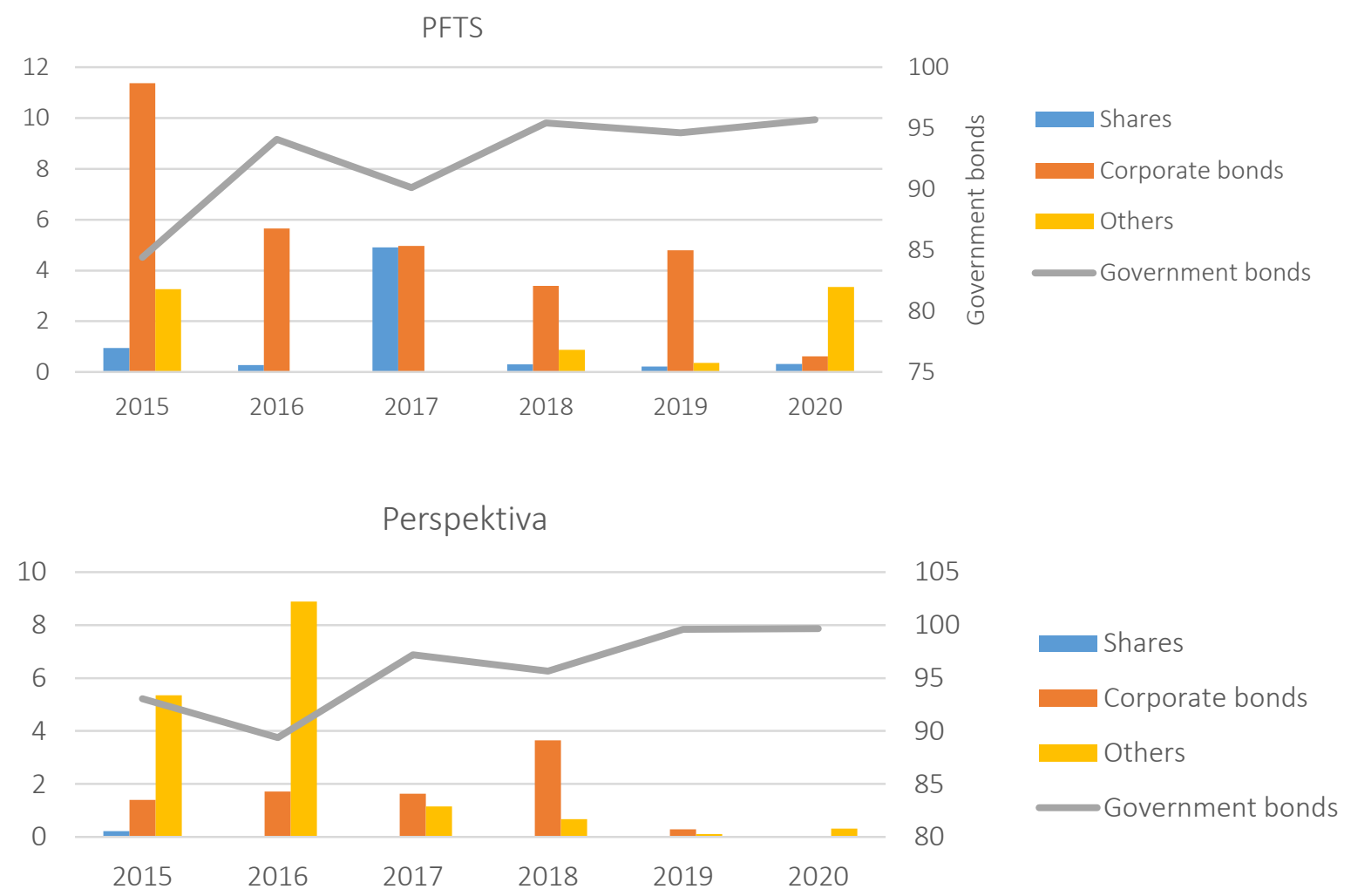

\section{Ukrainian Exchange}

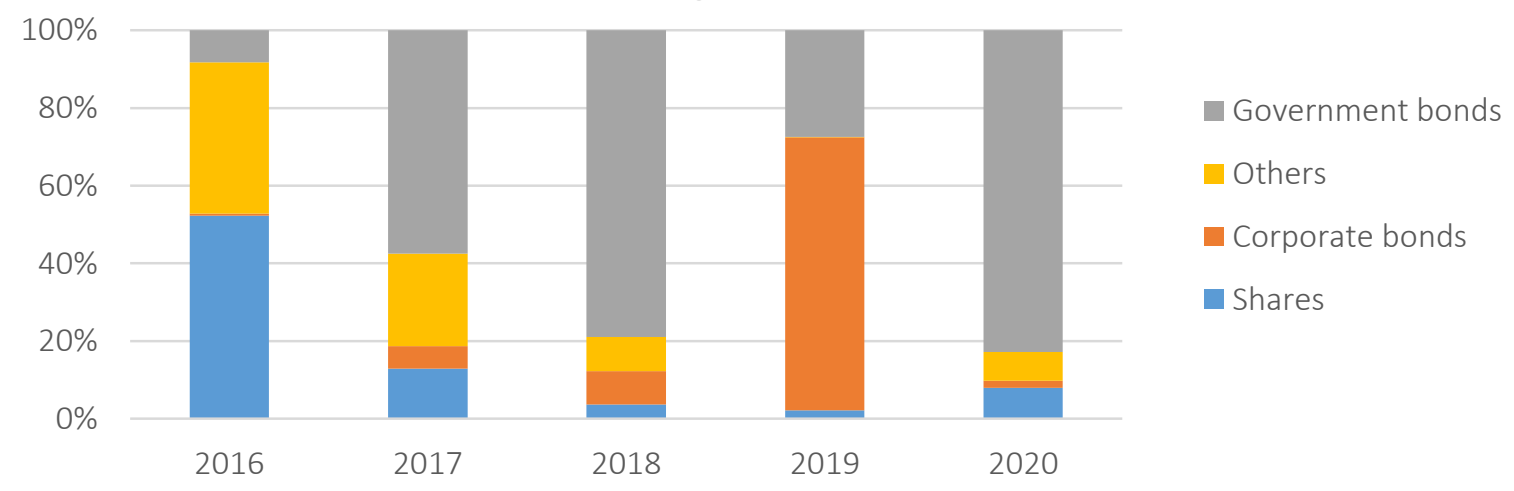

Figure 6. Structure of securities transactions in terms of stock exchanges in Ukraine

Since 2019, these stock exchanges also carry out transactions with shares of foreign issuers. The main platforms for operations with domestic government bonds are SE "PFTS" and SE "Perspektiva". Regarding corporate bonds, transactions with them take place on all platforms.

It should be noted that after the National Securities and Stock Market Commission (Ukraine) began processes aimed at removing speculative securities from the stock market, the requirements for shares and corporate bonds to be listed on the stock exchange and admitted to the stock exchange register were significantly raised. This, on the one hand, led to market cleansing, and, on the other hand, significantly reduced market capitalization and led to a revision and reduction of stock exchange baskets. In addition, a significant number of joint-stock companies, after changes in legislation and in approaches to determining the status of publicity, changed their legal form to private or limited liability companies and others, thereby confirming the absence of the need for an initial public offering of both shares and bonds. 


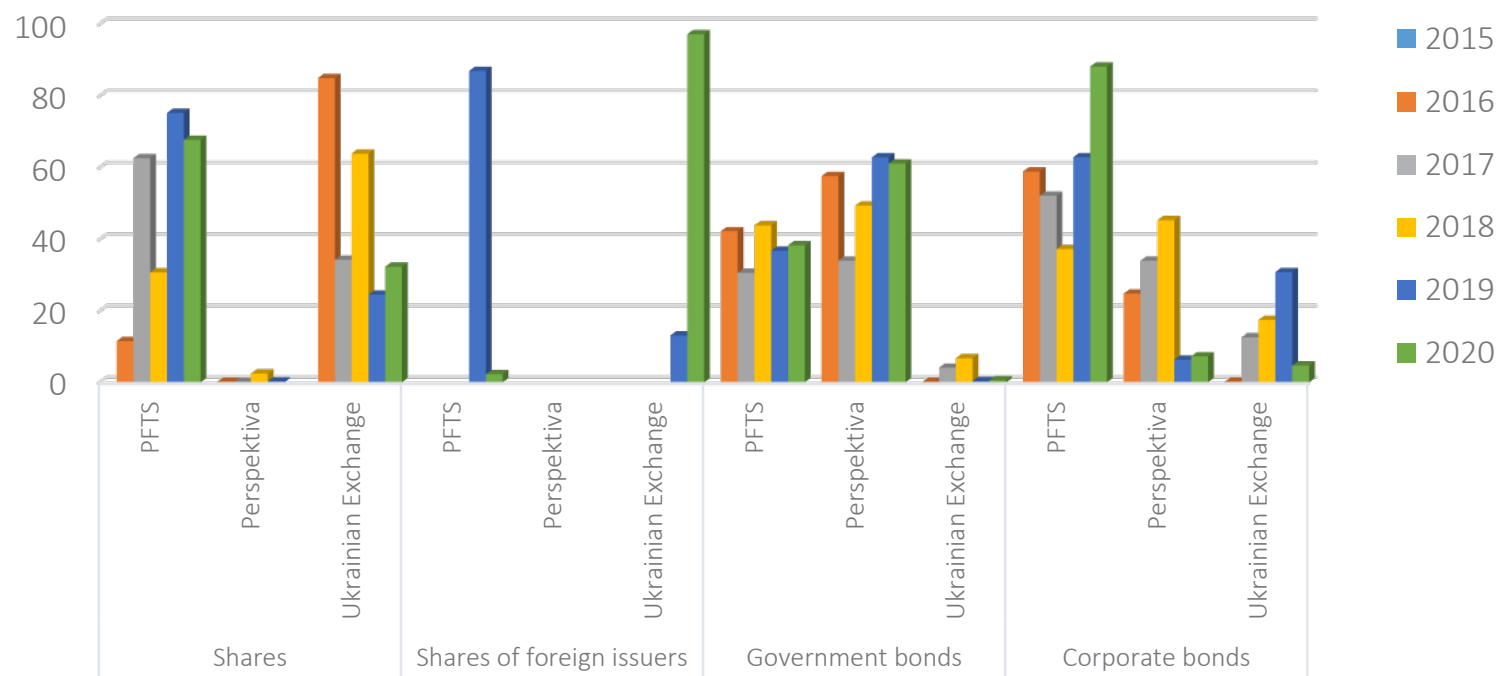

Figure 7. Distribution of securities transactions among stock exchanges in Ukraine

The analysis of transactions on Ukraine's stock market shows that it has small volumes of securities trading and, accordingly, does not perform its main function as a source of financing of economic entities' activities. This is the reason that among the rankings of global stock markets only the MSCI rating takes it into account and includes it in the list of markets that have an autonomous index (this is the PFTS index, which has long been calculated regularly and is considered one of the indicators characterizing the stock market conditions in Ukraine).

\subsection{Development forecasts of the Ukrainian stock market under the influence of world markets}

The Ukrainian economy is a small open economy and, therefore, it is significantly influenced by external factors. This includes the functioning of the stock market. To test this hypothesis, the paper analyzed the existing relationships between the functioning of Ukrainian stock exchanges and indicators characterizing the volume of trading in terms of the global stock market (according to the indicator of total trading on the world stock exchanges), in terms of the American and EMEA regions.

The analysis of securities trading dynamics on the stock exchanges in Ukraine shows a signifi- cant instability of such transactions. This applies to both SE "Perspektiva" and SE "PFTS" (Figure 8). Regarding the Ukrainian Stock Exchange, trading in certain periods was not conducted at all, or, compared to other exchanges, was completely insignificant. The dynamics of operations on the two main Ukrainian stock exchanges essentially determine the dynamics of operations in general on the stock market of Ukraine. Accordingly, forecast values have a significant scope of variation. This indicates a significant imbalance in the structure of operations. In addition, this situation is due to the small number of financial instruments on the stock exchange lists, compared to the stock exchange lists of world stock exchanges. Thus, as of 2020, the stock exchange list of SE "PFTS" included 50 shares of Ukrainian and foreign companies. For comparison, the number of companies in the SE Nasdaq - US listing in 2020 was 2,408, and 3,754 in the Japan Exchange Group listing.

The dynamics of trading volumes on world stock exchanges and in the analyzed regions are more stable and have an upward trend.

The Pearson pairwise correlation coefficients were calculated. The pairwise correlation matrix was built on the basis of initial data on the volume of trading on Ukraine's stock market as a whole and three real stock exchanges in Ukraine - PFTS (PFTS SE), "Perspektiva" (Perspektiva SE), and the 
Source: Authors' calculations.
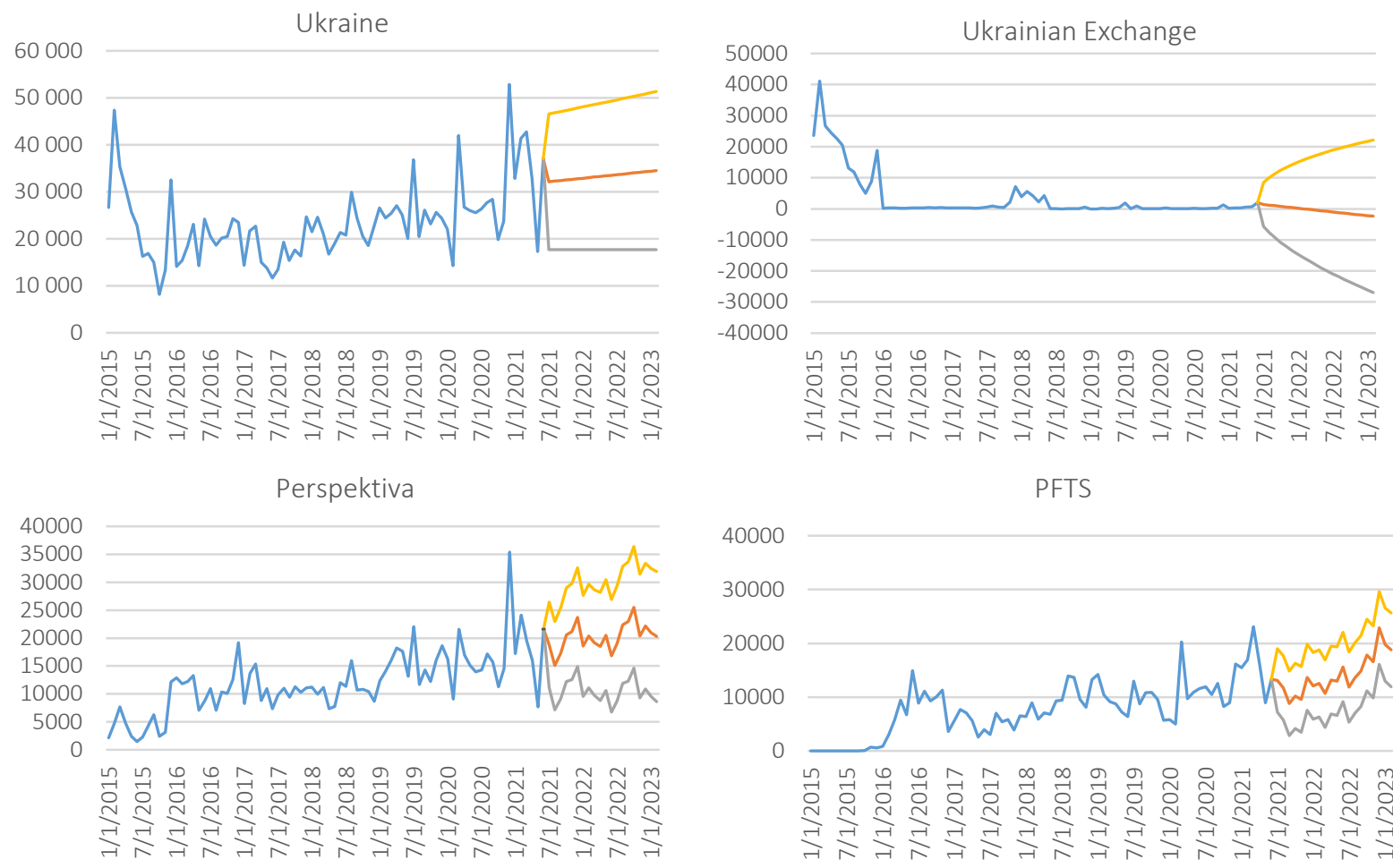

PFTS

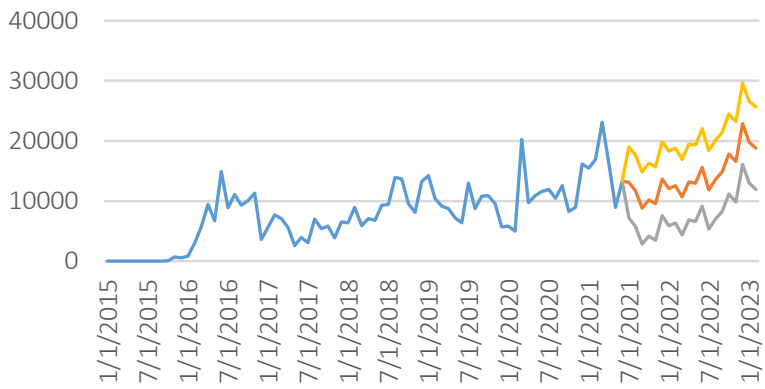

Americas

EMEA
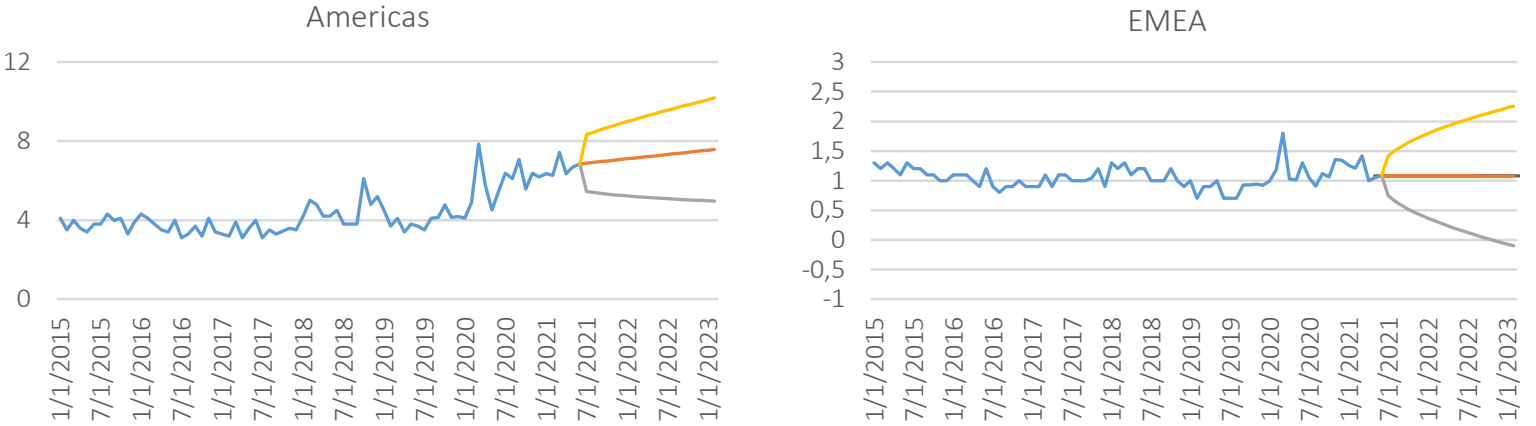

World

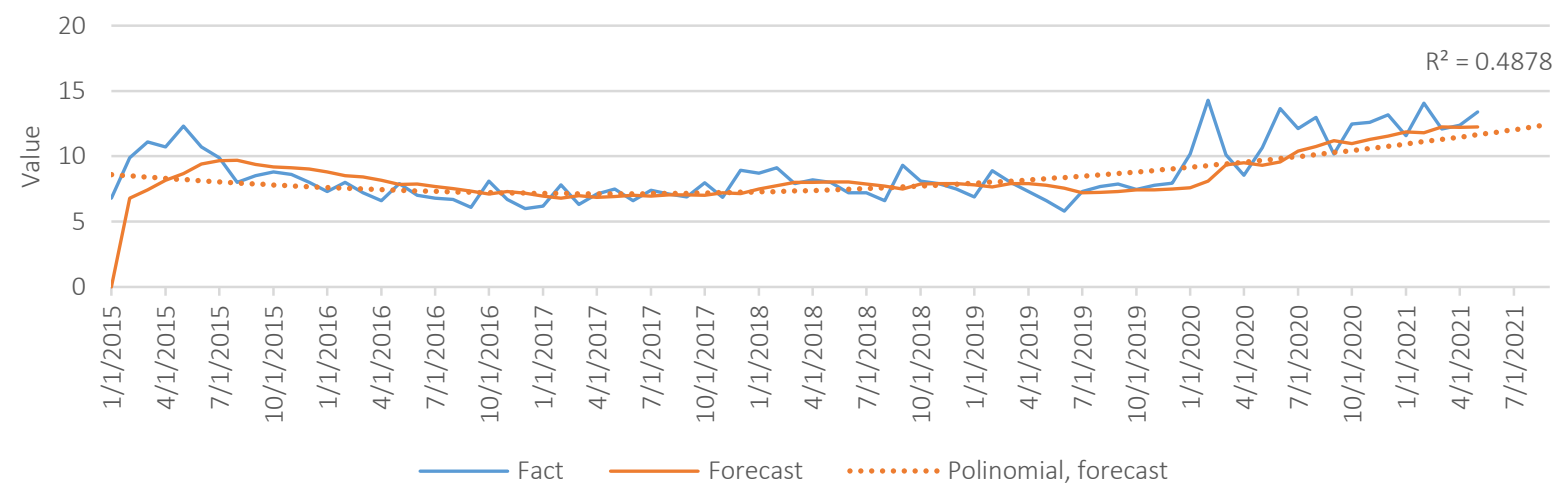

Figure 8. Dynamics of actual values and forecast of securities trading volumes in terms of stock markets and exchanges

Ukrainian Exchange (UE), as well as in terms of world trade, the US and EMEA regions. It showed no significant links between most of the presented variables.
If one assumes that the existence of the average level of communication is characterized by the value of correlation coefficient above 0.5 , then among the obtained results it is necessary to highlight the 
Table 1. Pairwise correlation matrix of securities trading volumes among stock markets and stock exchanges

Source: Authors' calculations.

\begin{tabular}{|c|c|c|c|c|c|c|c|}
\hline & Ukraine & EMEA & American & World & Ukrainian Exchange & Perspektiva & PFTS \\
\hline Ukraine & 1 & & & & & & \\
\hline EMEA & 0.316088 & 1 & & & & & \\
\hline American & 0.479892 & 0.511592 & 1 & & & & \\
\hline World & 0.474827 & 0.632035 & 0.846203 & 1 & & & \\
\hline Ukrainian Exchange & 0.274251 & 0.285079 & -0.21224 & 0.103718 & 1 & & \\
\hline Perspektiva & 0.615627 & 0.009495 & 0.466085 & 0.259738 & -0.49489 & 1 & \\
\hline PFTS & 0.516034 & 0.05597 & 0.598573 & 0.320233 & -0.57587 & 0.672843 & 1 \\
\hline
\end{tabular}

closest relationship 0.8462 , which exists between trading volumes on American stock exchanges and global trading. This result is quite logical because it is the region of stock exchanges with the world's leading positions - NYSE and Nasdaq US (see Figure 2), their share in global volume is gradually increasing over the past years based on the dynamics of indicators: $37.6 \%-2017,39.7 \%$ - 2018, 40.4\% - 2019, and 41.4\% - 2020, which makes this region a market leader. The results also indicate a less noticeable relationship between the EMEA region and global indicators, 0.632 .

The existence of the relationships between world markets and the functioning of Ukrainian stock exchanges manifests itself only between SE "PFTS" and the American region, which confirms earlier findings. There is a certain connection between operations on SE "PFTS" and SE "Perspektiva", the value of which is 0.6728 . It should be noted that the trading held on the Ukrainian Stock Exchange does not correlate with other Ukrainian stock exchanges, with the stock market of Ukraine as a whole, as well as with world stock markets. This is due to significant instability in the functioning of the exchange itself, due to several internal factors, including the change of owners and the structure of financial instruments in circulation.

To obtain more accurate calculations for building the regression model, time series were aligned by the moving average method (Appendix B) and by exponential smoothing (Figure 9) with a forecast based on the second-degree polynomial and approximation probability. The alignment by the moving average method gave a much smaller probability of approximation for all studied time series. The most accurate forecast was obtained based on the data of SE "Perspektiva" (0.8681), SE "PFTS" (0.8329), and the American region (0.7036). When performing exponential smoothing and taking into account the high volatility of trading volumes on stock markets, the smoothing coefficient that characterizes the influence of the attenuation factor is determined at the level of 0.8 . As a result of the calculations and the forecast based on the results of exponential smoothing, the tendency of growth on the Ukrainian stock markets, on SE "Ukrainian Exchange" and American stock markets, has been established. Insignificant growth is demonstrated by the polynomial of the EMEA region and world stock markets.

The results of exponential smoothing of time series were used to build regression models. The results of regression statistics, in particular, the mixed correlation coefficient $\mathrm{R}^{2}$, show that variations in the volume of trading on the world stock market by 0.766 are explained by the situation on the American stock markets. At the same time, the results concerning the role of American markets in the functioning of Ukrainian stock exchanges are more important. Thus, trading dynamics is determined on SE "Perspektiva" by $50.8 \%$ and on SE "PFTS" by $47.1 \%$ by the dynamics of trading on American stock exchanges, which is partly explained by the fact that these stock exchanges conduct insignificant trading in securities of foreign issuers. American stock markets have very little influence on the dynamics of trading on the Ukrainian Stock Exchange, but the trading on this exchange is not carried out permanently, and in some periods it is not carried out at all.

The time series of trading volume for the period from 2015 to June 2021 on the stock exchanges of Ukraine and the Ukrainian market in general (in contrast to global trends and trends emerging on stock markets of the American 
Source: Authors' calculations.
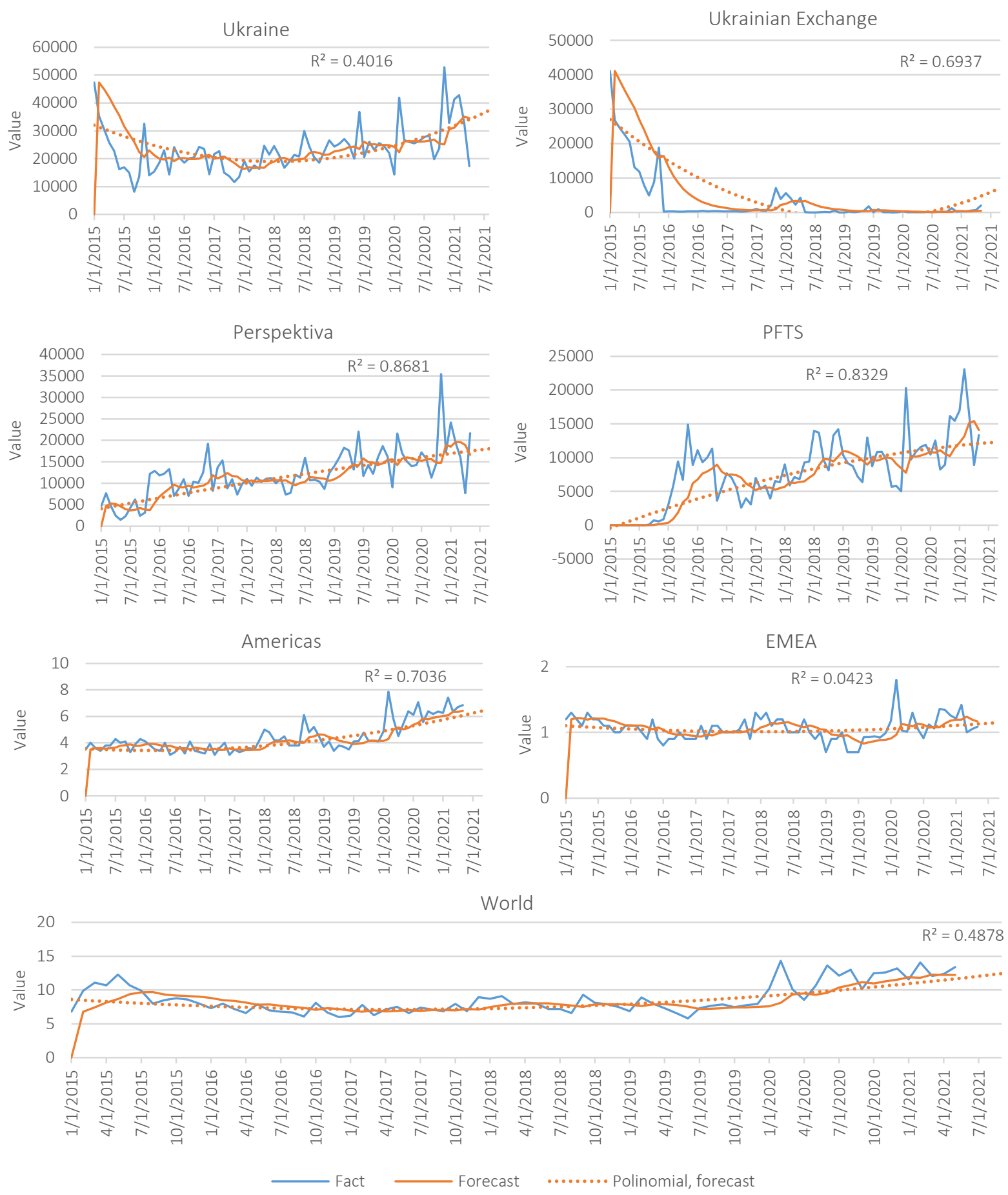

Figure 9. Dynamics of securities trading volume (actual, forecast based on exponential smoothing and polynomial trend)

and EMEA regions) are characterized by significant volatility. Their forecast values have a significant scope of variation, which characterizes them as high-risk ones. The relationship between the stock markets of the EMEA region and the world stock market can be described as an average based on the results of the pairwise correlation matrix, the existence of a close relationship between the stock exchanges of the American region, and the global stock market. The declining trend in trading on the Ukrainian stock exchanges SE "PFTS" and "Perspektiva" was confirmed on the basis of an exponentially smoothed time series. 
Table 2. Regression modeling of dependencies between stock markets and stock exchanges

Source: Authors' calculations.

\begin{tabular}{|c|c|c|c|c|c|c|}
\hline $\mathbf{Y}$ & $x$ & Multiple $R$ & $R$-square & $\begin{array}{c}\text { Normalized } \\
R \text {-square }\end{array}$ & Standard error & Regression equation \\
\hline World & American & 0.875443 & 0.766401 & 0.763245 & 0.733110 & $1.683+1.59 X_{\text {iy }}$ \\
\hline World & EMEA & 0.651483 & 0.424430 & 0.416546 & 0.079412 & $0.679+0.045 X_{i y}$ \\
\hline Perspektiva & American & 0.712696 & 0.507935 & 0.501194 & 2829.12951 & $-3063.45+3436.04 X_{i y}$ \\
\hline PFTS & American & 0.686604 & 0.471425 & 0.464184 & 2907.68747 & $-6657.9+3282.571 x_{i y}$ \\
\hline $\begin{array}{l}\text { Ukrainian } \\
\text { Exchange }\end{array}$ & American & 0.322070 & 0.103729 & 0.091451 & 0.791965 & $4.383-0.00003 X_{i y}$ \\
\hline Perspektiva & EMEA & 0.275256 & 0.075765 & 0.063276 & 3924.688 & $22730.175-10677.58 X_{i y}$ \\
\hline PFTS & EMEA & 0.288886 & 0.083455 & 0.071069 & 3886.491 & $18973.92-11143.7 X_{i y}$ \\
\hline $\begin{array}{l}\text { Ukrainian } \\
\text { Exchange }\end{array}$ & EMEA & 0.532866 & 0.283947 & 0.27427 & 8433.517233 & $-48120.22+50463.42 X_{i y}$ \\
\hline Ukraine & PFTS & 0.027486 & 0.000755 & -0.012933 & 5845.49599 & $23609.12+0.0402 X_{i y}$ \\
\hline Ukraine & Perspektiva & 0.094839 & 0.008994 & -0.004581 & 5821.34763 & $22319.64+0.3655 X_{i y}$ \\
\hline Ukraine & Ukrainian Exchange & 0.569384 & 0.324198 & 0.314940 & 4807.23426 & $22103.42+0.3655 X_{i y}$ \\
\hline
\end{tabular}

\section{CONCLUSION}

The study allowed only partially confirming the hypothesis about the influence of the global stock market and stock markets of individual regions on the current state and vectors of further development of the Ukrainian stock market. The results obtained confirmed the influence of the stock market of the American region on the dynamics of securities trading on the SE "PFTS" and SE "Perspektiva" at a level not exceeding 50\%. Although geographically, the Ukrainian stock market belongs to the EMEA region, there is no influence of the stock market of this region on the dynamics of securities trading on Ukrainian stock exchanges. At the same time, the obtained results of the constructed regressions provide a basis for further research using models that make it possible to determine the presence of nonlinear dependences.

\section{AUTHOR CONTRIBUTIONS}

Conceptualization: Inna Shkolnyk.

Data curation: Serhiy Frolov.

Formal analysis: Volodymyr Orlov, Viktoriia Dziuba.

Funding acquisition: Yevgen Balatskyi.

Investigation: Serhiy Frolov, Viktoriia Dziuba.

Methodology: Inna Shkolnyk, Volodymyr Orlov.

Project administration: Inna Shkolnyk.

Resources: Yevgen Balatskyi.

Software: Viktoriia Dziuba.

Supervision: Inna Shkolnyk.

Validation: Viktoriia Dziuba, Volodymyr Orlov.

Visualization: Serhiy Frolov, Volodymyr Orlov.

Writing - original draft: Volodymyr Orlov, Viktoriia Dziuba.

Writing - review \& editing: Serhiy Frolov. 


\section{REFERENCES}

1. Bulatova, O., Marena, T., Chentukov, Y., \& Shabelnyk, T. (2020). The impact of global financial transformations on the economic security of Central and Eastern European countries. Public and Municipal Finance, 9(1), 1-13. https://doi. org/10.21511/pmf.09(1).2020.01

2. Caporale, G. M., Gil-Alana, L., \& You, K. (2019). Stock market linkages between the ASEAN countries, China and the US: a fractional cointegration approach (CESifo Working Paper No. 7537). Munich. Retrieved from https://www.cesifo.org/en/ publikationen/2019/working-paper/ stock-market-linkages-betweenasean-countries-china-and-us

3. Diaz, J. F. (2021). Dynamic volatility spillovers across the Extended Greater China Region stock markets. Global Economy Journal, 21(1). https://doi.org/10.1142/ S2194565921500032

4. Ebrahimi, S. K., Nasab, A. B., \& Karim, M. (2016). Evaluating the effect of accruals quality, investments anomaly and quality of risk on risk premium (return) of stock of listed companies in Tehran Stock Exchange. Problems and Perspectives in Management, 14(3-si), 296-306. https://doi.org/10.21511/ppm.14(3si).2016.01

5. FTSE. (2021). FTSE Country Classification of Equity Markets. Retrieved from https://research.ftserussell. com/products/downloads/Matrixof-Markets_latest.pdf

6. Gulzar, S., Kayani, G. M., Xiaofeng, H., Ayub, U., \& Rafique, A. (2019). Financial cointegration and spillover effect of global financial crisis: a study of emerging Asian financial markets. Economic Research-Ekonomska Istraživanja, 32(1), 187-218. https://doi.org/10.1080/133167 7X.2018.1550001

7. Hayati, K., \& Sedaghat, P. (2016). An evaluation of the links between quality of reporting and efficiency of investment in companies listed at Tehran Stock Exchange. Problems and Perspectives in Management, 14(3-si), 341-347. https://doi. org/10.21511/ppm.14(3-si).2016.06
8. Hurduzeu, G., Lupu, R., Lupu, I., \& Filip, R. I. (2021). Transmission of external shocks on the Romanian capital market. Economic Computation and Economic Cybernetics Studies and Research, 55(1), 41-56. https://doi.org/10.24818/18423264/ 55.1.21.03

9. Krkošková, R. (2020). Impact of stock markets on the economy in the V4 countries. E\& $M$ Economics and Management, 23(3), 138154. https://doi.org/10.15240/ tul/001/2020-3-009

10. Lupu, L. (2015). European stock markets correlations in a Markov switching framework. Romanian Journal of Economic Forecasting, 18(3), 103-119. Retrieved from https:/econpapers.repec.org/article/ rjrromjef/v_3a_3ay_3a2015_3ai_3a 3_3ap_3a103-119.htm

11. Mishra, P. K., \& Mishra, S. K. (2020) Corona pandemic and stock market behaviour: Empirical insights from selected Asian countries. Millennial Asia, 11(3), 341-365. https://doi. org/10.1177/0976399620952354

12. MSCI. (n.d.). Market cap indexes. Retrieved from https://www.msci. com/market-cap-weighted-indexes

13. Nguyen, P. H. (2021). Impact of macroeconomic factors and interaction with institutional performance on Vietnamese bank share prices. Banks and Bank Systems, 16(1), 127-137. https://doi.org/10.21511/ bbs.16(1).2021.12

14. Phuong, L. C. M. (2021). How COVID-19 impacts Vietnam's banking stocks: An event study method. Banks and Bank Systems, 16(1), 92-102. https://doi.org/10.21511/ bbs.16(1).2021.09

15. Plastun, A., Kozmenko, S., Plastun, V., \& Filatova, H. (2019). Market anomalies and data persistence: The case of the day-of-the-week effect. Journal of International Studies, 12(3), 122-130. https://doi. org/10.14254/2071-8330.2019/12$3 / 10$

16. Plastun, A., Makarenko, I., \& Balatskyi, I. (2018). Competitiveness in the Ukrainian stock market and local crisis of 2013-2015. Invest- ment Management and Financial Innovations, 15(2), 29-39. https://doi. org/10.21511/imfi.15(2).2018.03

17. Rai, K., \& Garg, B. (2021). Dynamic correlations and volatility spillovers between stock price and exchange rate in BRIICS economies: Evidence from the COVID-19 outbreak period. Applied Economics Letters. https://doi.org/10.1080/13504851.2 021.1884835

18. S\&P Dow Jones Indices. (2020). Se $P$ P Dow Jones Indices' 2020 Country Classification Consultation. Retrieved from https://www. spglobal.com/spdji/en/documents/indexnews/announcements/20200819-1206359/1206359_spdji2020countryclassificationconsultation8-19-2020.pdf

19. Salamat, W. A., Momani, M. Q. M., \& Batayneh, K. (2021). Firmspecific, macroeconomic factors and stock price risk for Jordanian banks. Banks and Bank Systems, 16(3), 166-172. http://dx.doi. org/10.21511/bbs.16(3).2021.15

20. Shkolnyk, I., Kozmenko, S., Kozmenko, O., \& Mershchii, B. (2019). The impact of economy financialization on the level of economic development of the associate EU member states. Economics and Sociology, 12(4), 43-58. https://doi.org/10.14254/2071789X.2019/12-4/2

21. Shkolnyk, I., Kozmenko, S., Polach, J., \& Wolanin, E. (2020). State financial security: Comprehensive analysis of its impact factors. Journal of International Studies, 13(2), 291309. https://doi.org/10.14254/2071$8330.2020 / 13-2 / 20$

22. The World Federation of Exchanges. (n.d.). Welcome to the Future of Markets. Retrieved from https:// www.world-exchanges.org/

23. Zhang, P., Gao, J., Zhang, Y., \& Wang, T. (2021). Dynamic spillover effects between the US stock volatility and chinass stock market crash risk: A TVP-VAR approach. Mathematical Problems in Engineering, 2021. https://doi. org/10.1155/2021/6616577 


\section{APPENDIX A}

Table A1. Stock market classification

\begin{tabular}{|c|c|}
\hline Ranking & Classification and countries \\
\hline \multirow{4}{*}{ FTSE } & $\begin{array}{l}\text { Developed ( } 26 \text { countries): Australia, Austria, Belgium / Luxembourg, United Kingdom, Hong Kong, } \\
\text { Denmark, Israel, Ireland, Spain, Italy, Canada, Netherlands, Germany, New Zealand, Norway, South Korea, } \\
\text { Poland, Portugal, Singapore, USA, Finland, France, Sweden, Switzerland, Japan. }\end{array}$ \\
\hline & $\begin{array}{l}\text { Advanced emerging (10 countries): Brazil, Greece, Malaysia, Mexico, South Africa, Thailand, Taiwan, } \\
\text { Turkey, Hungary, Czech Republic. }\end{array}$ \\
\hline & $\begin{array}{l}\text { Secondary emerging (14 countries): Egypt, India, Indonesia, Qatar, China, Colombia, Kuwait, UAE, } \\
\text { Pakistan, Russian Federation, Romania, Saudi Arabia, Philippines, Chile. }\end{array}$ \\
\hline & $\begin{array}{l}\text { Frontier (30 countries): Bangladesh, Bahrain, Bulgaria, Botswana, Ghana, Estonia, Iceland, Jordan, } \\
\text { Kazakhstan, Cyprus, Kenya, Ivory Coast, Latvia, Lithuania, Mauritius, Malta, Morocco, Nigeria, Oman, } \\
\text { Palestine, Peru, Northern Republic Macedonia, Serbia, Slovak Republic, Slovenia, Tanzania, Tunisia, } \\
\text { Vietnam, Croatia, Sri Lanka. }\end{array}$ \\
\hline \multirow{4}{*}{$\mathrm{MSCl}$} & $\begin{array}{l}\text { Developed ( } 23 \text { countries): Australia, Austria, Belgium, United Kingdom, Hong Kong, Denmark, Israel, } \\
\text { Ireland, Spain, Italy, Canada, Netherlands, Germany, New Zealand, Norway, Portugal, Singapore, USA, } \\
\text { Finland, France, Sweden, Switzerland, Japan. }\end{array}$ \\
\hline & $\begin{array}{l}\text { Emerging (27 countries): Argentina, Brazil, Greece, Egypt, India, Indonesia, Qatar, China, Korea, Colombia, } \\
\text { Kuwait, Malaysia, Mexico, UAE, Pakistan, South Africa, Peru, Poland, Russian Federation, Saudi Arabia, } \\
\text { Taiwan, Thailand, Turkey, Hungary, Philippines, Czech Republic, Chile. }\end{array}$ \\
\hline & $\begin{array}{l}\text { Frontier (19 countries): Bahrain, Bangladesh, Vietnam, Estonia, Iceland, Jordan, Lithuania, Kazakhstan, } \\
\text { Kenya, Mauritius, Morocco, Nigeria, Oman, Romania, Serbia, Slovenia, Tunisia, Croatia, Sri Lanka. }\end{array}$ \\
\hline & $\begin{array}{l}\text { Standalone market index (11 countries): Bulgaria, Bosnia and Herzegovina, Botswana, Zimbabwe, Libya, } \\
\text { Malta, Palestine, Panama, Trinidad and Tobago, Ukraine, Jamaica. }\end{array}$ \\
\hline \multirow{3}{*}{ S\&P Dow Jones Indices } & $\begin{array}{l}\text { Developed ( } 25 \text { countries): Australia, Austria, Belgium, United Kingdom, Hong Kong, Denmark, Israel, } \\
\text { Ireland, Spain, Italy, Canada, Luxembourg, Netherlands, Germany, New Zealand, Norway, South Korea, } \\
\text { Portugal, Singapore, USA, Finland France, Sweden, Switzerland, Japan. }\end{array}$ \\
\hline & $\begin{array}{l}\text { Emerging (26 countries): Brazil, Greece, Egypt, India, Indonesia, Qatar, China, Colombia, Kuwait, Malaysia, } \\
\text { Mexico, UAE, Pakistan, South Africa, Peru, Poland, Russia, Saudi Arabia, Taiwan, Thailand, Turkey, Hungary, } \\
\text { Philippines, Czech Republic, Chile. }\end{array}$ \\
\hline & $\begin{array}{l}\text { Frontier (31 countries): Argentina, Bahrain, Bangladesh, Bulgaria, Botswana, Vietnam, Ghana, Estonia, } \\
\text { Zambia, Jordan, Latvia, Libya, Lithuania, Kazakhstan, Kenya, Cyprus, Ivory Coast, Mauritius, Morocco, } \\
\text { Namibia, Nigeria, Oman, Panama, Romania, Slovakia, Slovenia, Trinidad and Tobago, Tunisia, Croatia, Sri } \\
\text { Lanka, Jamaica. }\end{array}$ \\
\hline
\end{tabular}



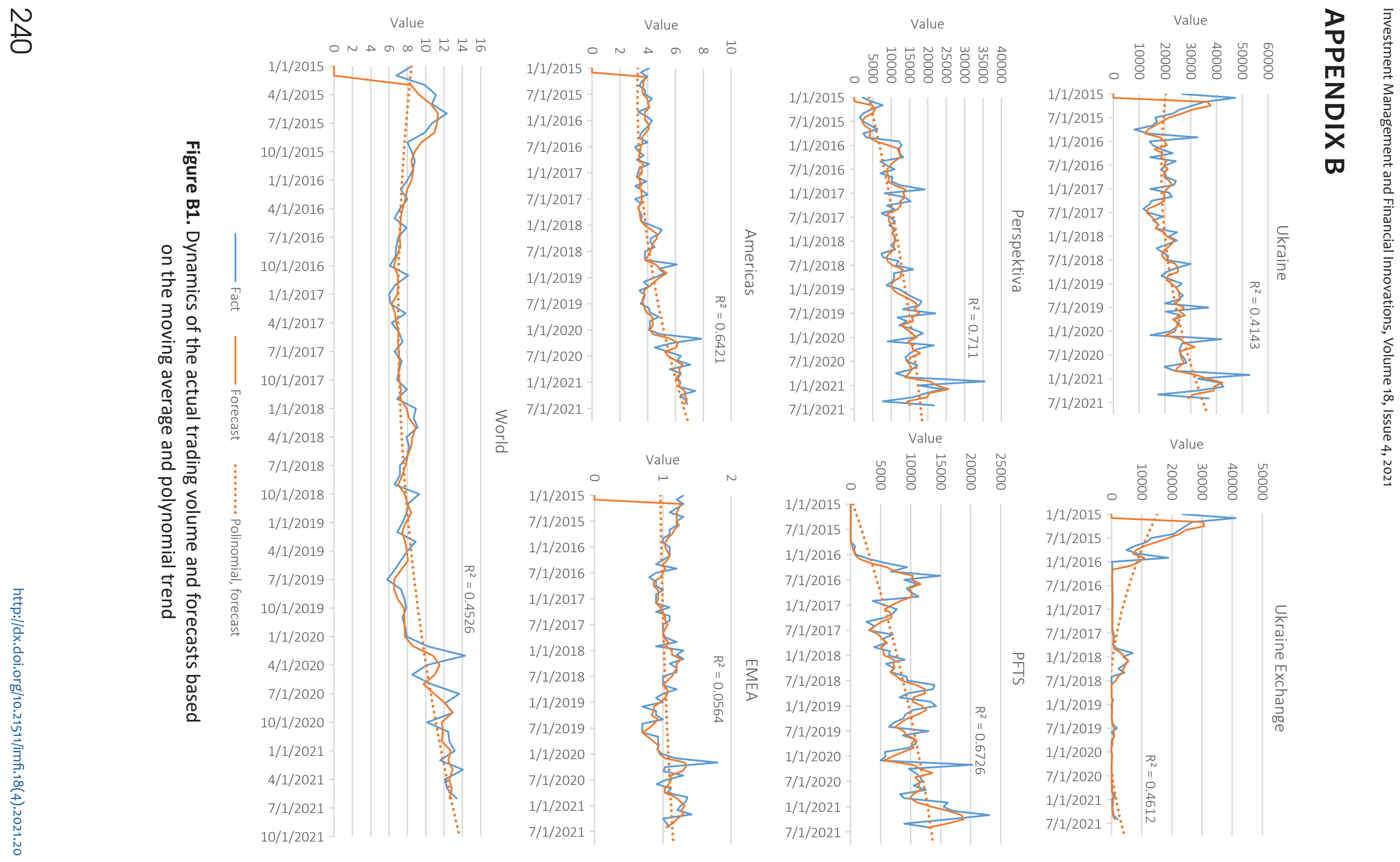

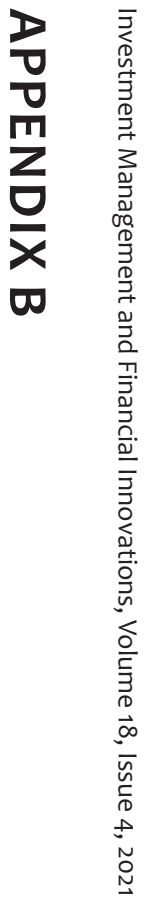

合 